\title{
Neuropeptide Y-Like Immunoreactivity in Bullfrog Sympathetic Ganglia is Restricted to C Cells
}

\author{
John P. Horn, William D. Stofer, and Sahba Fatherazi \\ Department of Physiology, University of Pittsburgh, School of Medicine, Pittsburgh, Pennsylvania 15261
}

Staining the entire chain of paravertebral sympathetic ganglia in the bullfrog with an antiserum against porcine neuropeptide $Y$ (NPY) revealed that, in each ganglion, a subpopulation of neurons expresses NPY-like immunoreactivity. Chromaffin cells in the sympathetic ganglia and in the adrenal gland were not stained by the anti-NPY serum. Since neurons in ganglia 9 and 10 of the sympathetic chain can be classified into 3 distinct groups on the basis of established electrophysiological criteria, we sought to identify the neurons in these ganglia that contain the NPY-like immunoreactivity. Accordingly, a series of cells was impaled with intracellular recording electrodes, identified as either fast B-, slow B-, or C-type neurons, filled with Lucifer yellow, and then processed with the anti-NPY serum for indirect immunofluorescence. These double-label experiments revealed that NPY-like immunoreactivity is expressed selectively by C-type sympathetic neurons. Counts of immunoreactive cells indicate that $55 \%$ of the neurons in ganglia 9 and 10 are C cells.

A major target of the $C$ cells appears to be the vasculature. In 3 different tissues innervated by sympathetic neurons, namely, the adrenal gland, the sartorius muscle, and the skin of the hindlimb, axons containing NPY-like immunoreactivity were found primarily within or near blood vessels. Within 14-60 d after extirpation of sympathetic ganglia 9 and 10 , most immunoreactive axons in the sartorius muscle and nearby skin disappeared. In conjunction with other evidence, the possibility arises that sympathetic $\mathbf{C}$ cells function as vasomotor neurons that use an NPY-like substance and epinephrine as cotransmitters.

Neuropeptide Y (NPY) is a member of the pancreatic polypeptide family that has been purified from porcine brain and sequenced (Tatemoto, 1982; Tatemoto et al., 1982). In the mammalian sympathetic system, NPY is localized in subsets of pre- and paravertebral ganglion cells (Lundberg et al., 1982a, b, 1983) and in axons that project to cardiac (Gu et al., 1983; Lundberg et al., 1983) and smooth muscle (Edvinsson et al., 1983; Lundberg et al., 1983, 1984; Stjernquist et al., 1983).

\footnotetext{
Received July 21, 1986; revised Nov. 28, 1986; accepted Dec. 15, 1986.

This work was supported by grants from the National Institutes of Health (NS21065) and the Keystone Pennsylvania Chapter of the American Heart Association. W.D.S. is a research fellow of the Western Pennsylvania Chapter of the American Heart Association and J.P.H. is an Alfred P. Sloan Research Fellow. We wish to thank Walter Stewart for a sample of Lucifer yellow $\mathrm{CH}$ and Jane Dodd, Tom Jessell, and Story Landis for help with preliminary immunocytochemical experiments.

Correspondence should be addressed to Dr. John P. Horn at the above address.

Copyright (C) 1987 Society for Neuroscience $0270-6474 / 87 / 061717-11 \$ 02.00 / 0$
}

Application of exogenous NPY has been shown to alter cardiac contractility (Allen et al., 1983b; Franco-Cereceda et al., 1985), to inhibit the nerve-evoked release of norepinephrine from sympathetic fibers (Lundberg and Stjarne, 1984; Franco-Cereceda et al., 1985), and to stimulate vasoconstriction (Lundberg et al., 1982b; Edvinsson et al., 1983; Edwall et al., 1985; FrancoCereceda et al., 1985; Hellstrom et al., 1985). Some effects of NPY can be mimicked by stimulating sympathetic axons in the presence of catecholamine receptor antagonists (Edwall et al., 1985; Hellstrom et al., 1985; Lundberg and Stjarne, 1984). Together, these results suggest that NPY and norepinephrine are cotransmitters in a subpopulation of mammalian sympathetic neurons and that NPY plays an important role in regulating the circulation. However, the electrophysiological properties of NPYcontaining sympathetic neurons are unknown. The present experiments were undertaken to examine this issue in the ninth and tenth paravertebral ganglia of the bullfrog (Rana catesbiana).

Classification of the sympathetic neurons in paravertebral ganglia 9 and 10 of the bullfrog as fast $B$, slow $B$, and C cells is based on the conduction velocities of pre- and postganglionic axons, the segmental origins of preganglionic axons, and cell body size (Dodd and Horn, 1983). Even though the anatomical simplicity of amphibian ganglia has, to date, been exploited primarily for its technical advantages in studies of synaptic physiology (Kuffler, 1980), amphibia may also provide useful models for analyzing subsystems within sympathetic ganglia. At present, the functional roles played by subclasses of bullfrog sympathetic neurons have not been delineated completely, but preliminary mapping experiments suggest that $B$ and $C$ cells project to different types of targets (Horn et al., 1985, 1986). As in the frog, the conduction velocities of pre- and postganglionic axons in mammals are clustered into different groups within the B- and C-fiber ranges (Dunant, 1967; Erulkar and Woodward, 1968; Perri et al., 1970; Wallis and North, 1978; Janig and Szulczyk, 1981; Hartman and Krier, 1984). Moreover, Janig and Szulczyk (1981) have proposed that conduction velocity in the cat paravertebral sympathetic system is a correlate of functional specificity. They have found, for example, that vasomotor axons characteristically conduct in the $\mathrm{C}$-fiber range. As yet, however, no general scheme for cell classification can easily be applied to all segmental levels of the sympathetic chain and to different species. In the hope of uncovering principles of functional organization that are conserved in many vertebrates, we have begun to examine the cellular distribution of neuropeptides in bullfrog chain ganglia. We became interested in NPY because it had already been implicated in the regulation of the cardiovascular system, a universally important function. 
Table 1. NPY-like immunoreactivity of electrophysiologically identified sympathetic neurons

\begin{tabular}{|c|c|c|c|c|c|c|}
\hline \multirow[b]{2}{*}{ Cell type } & \multirow{2}{*}{$\begin{array}{l}\text { No. of } \\
\text { cells } \\
\text { filled } \\
\text { with } \\
\text { Lucifer } \\
\text { yellow }\end{array}$} & \multirow{2}{*}{$\begin{array}{l}\text { Resting potential } \\
(\mathrm{mV})\end{array}$} & \multicolumn{2}{|c|}{ Conduction velocity $(\mathrm{m} / \mathrm{sec})$} & \multirow{2}{*}{$\begin{array}{l}\text { No. of } \\
\text { cells re- } \\
\text { covered } \\
\text { after } \\
\text { identifi- } \\
\text { cation }\end{array}$} & \multirow[t]{2}{*}{$\begin{array}{l}\text { Recov- } \\
\text { ered } \\
\text { cells } \\
\text { that } \\
\text { were } \\
\text { immu- } \\
\text { noreac- } \\
\text { tive (\%) }\end{array}$} \\
\hline & & & Orthodromic & Antidromic & & \\
\hline Fast B & 58 & $-46.8 \pm 8.9(n=58)$ & $2.46 \pm 0.81(n=58)$ & $2.54 \pm 0.91(n=58)$ & 54 & 1.8 \\
\hline Slow B & 57 & $-43.2 \pm 9.9(n=55)$ & $2.66 \pm 0.87(n=57)$ & $0.56 \pm 0.18(n=57)$ & 55 & 0.0 \\
\hline $\mathrm{C}$ & 88 & $-44.1 \pm 11.2(n=86)$ & $0.43 \pm 0.13(n=88)$ & $0.32 \pm 0.08(n=58)$ & 86 & 88.3 \\
\hline
\end{tabular}

Resting potentials and conduction velocities are expressed as the mean \pm SD. $n$, number of cells included in each statistic.

\section{Materials and Methods}

Immunocytochemistry. Four to 5 in. bullfrogs of both sexes (Charles D. Sullivan Co., Nashville, TN) were anesthetized by immersion in $0.4 \%$ tricaine methanesulfonate and then perfused through the aorta with 50 $\mathrm{ml}$ of Ringer's solution, followed by $150 \mathrm{ml}$ of cold $4 \%$ paraformaldehyde in PBS. Paravertebral ganglia 2-10 (same nomenclature as in Dodd and Horn, 1983) were dissected free on both sides, postfixed for $1 \mathrm{hr}$, and placed overnight at $4^{\circ} \mathrm{C}$ in $25 \%$ sucrose in phosphate buffer. Ten micron cryostat sections were cut, mounted on gelatin-coated slides, washed for $20 \mathrm{~min}$ in $3 \%$ goat serum in $0.1 \mathrm{M}$ PBS, and incubated overnight at $4^{\circ} \mathrm{C}$ with a 1:800 dilution of rabbit anti-NPY serum (RPN 1702; Amersham, Arlington Heights, IL) with $0.1 \%$ Triton X-100 and $1 \%$ goat serum in PBS. The antiserum was made against porcine NPY. After three 5-min washes in PBS, the sections were incubated in a 1:150 dilution of rhodamine-coupled goat anti-rabbit serum (6330; Tago, Burlingame, $\mathrm{CA}$ ) in PBS for $30 \mathrm{~min}$ at room temperature. The slides were then rinsed 3 times in PBS, coverslipped in 1:1 PBS:glycerin, and viewed under a Zeiss microscope with an HBO 50 epifluorescence illuminator and an appropriate filter set (48-77-15; Zeiss, Thornwood, NY). Sections of adrenal gland, skin, and muscle were processed in the same manner. The authentic porcine NPY used in preabsorption controls was purchased from Calbiochem, La Jolla, CA.

Physiological recording and double-labeling. The procedure for isolating chain ganglia 7-10 and recording was similar to that described previously (Dodd and Horn, 1983), except for the inclusion of an epifluorescent light source on the compound microscope used to visualize neurons while recording (fixed-stage modification of Zeiss WL with $40 \times$ water immersion objective and Nomarski differential interference contrast). This microscope was used to monitor the injection of fluorescent dye into identified living neurons and to examine tissue after it had been processed for immunofluorescence.

Individual ganglion cells were impaled first with a $3 \mathrm{M} \mathrm{KCl}$-filled microelectrode and identified using the electrophysiological criteria of Dodd and Horn (1983), which are summarized in Results. In each preparation, 5-20 cells belonging to one class were filled by iontophoretic injection from a second microelectrode containing a 3\% solution of Lucifer yellow CH (gift of Walter Stewart) in water. After recording from a preparation, its dimensions were measured so that the latencies of orthodromic and antidromic responses could be expressed as conduction velocities (Table 1). The preparation was then fixed by immersion for $1 \mathrm{hr}$ in cold 4\% paraformaldehyde in PBS, allowed to sink overnight in phosphate-buffered sucrose, and serially sectioned. Sections containing cells filled with Lucifer yellow were identified using Zeiss FITC filter set 48-77-10 and processed for immunocytochemistry as described above.

Cell counts. In order to determine the percentage of neurons in ganglia 9 and 10 that contains NPY-like immunoreactivity, ganglia on one side in 3 perfusion-fixed animals were prepared as described above and sectioned serially at $10 \mu \mathrm{m}$. The NPY immunocytochemistry was modified by using an HRP-coupled second antibody instead of a rhodaminecoupled antibody. After exposure to the anti-NPY serum and washing, the HRP-coupled goat anti-rabbit serum (6430; Tago) was applied at a dilution of 1:800 for $2 \mathrm{hr}$ at room temperature. Then, after three $5 \mathrm{~min}$ washes in PBS, the sections were preincubated for $5 \min$ in $0.1 \mathrm{mg} / \mathrm{ml}$ of 3,3'-diaminobenzidene (DAB) in PBS and reacted for $20 \mathrm{~min}$ in 0.1 $\mathrm{mg} / \mathrm{ml} \mathrm{DAB}$ and $0.01 \% \mathrm{H}_{2} \mathrm{O}_{2}$. Following 3 subsequent washes in PBS, the sections were counterstained with thionin, dehydrated in graded alcohols, cleared in xylenes, and coverslipped with Permount.

The reacted sections were examined at a magnification of $500 \times$ so that all cellular profiles containing nucleoli could be drawn using a camera lucida and scored for the presence of immunoreactivity. The numbers of labeled and unlabeled profiles were then counted from the drawings. To correct for split nucleoli, the correction factors of Abercrombie (1946) and Konigsmark (1970) were calculated. For this purpose, nucleoli from 150 immunoreactive and 150 nonimmunoreactive neurons were drawn at a magnification of $1845 \times$, measured along their longest axis, and found to have diameters of $3.6 \pm 0.7$ and $4.2 \pm 0.7$ (mean $\pm \mathrm{SD}$ ) $\mu \mathrm{m}$, respectively. No correction was made for cells with double nucleoli. Abercrombie's method gave correction factors of 0.73 and 0.70 for immunoreactive and nonimmunoreactive cells. Using the assumption that fragments of nucleoli smaller than $1 \mu \mathrm{m}$ could not be recognized, Konigsmark's method gave correction factors of 0.74 and 0.71 for immunoreactive and nonimmunoreactive cells. Since both methods give similar corrections and Abercrombie's (1946) does not contain an assumption about resolution, the counts in Table 3 were corrected using Abercrombie's formula.

Whole mounts. Whole mounts of the sartorius muscle were stained using a modification of the procedure described by Costa et al. (1980). In brief, paraformaldehyde-fixed muscles were prepared either by a 1 $\mathrm{hr}$ immersion of a freshly dissected muscle that had been pinned out or by vascular perfusion of an animal, followed by dissection and postfixation for $1 \mathrm{hr}$. The fixed muscles were dehydrated through graded alcohols and cleared in xylenes. Finally, the defatted tissue was rehydrated through graded alcohols and processed for immunoreactivity using the anti-NPY serum and a second antibody coupled to HRP.

In addition to using bullfrogs, we stained several sartorius muscles from 2 in. grass frogs, Rana pipiens, as whole mounts. There was no discernible difference between bullfrogs and grass frogs in the pattern of staining. Figure $7 b$ is the only picture of staining in muscle from a grass frog that is presented in this paper.

Extirpation surgery. To assess the origin of NPY-like immunoreactivity in peripheral tissues, sympathetic ganglia were removed surgically from 5 animals. After anesthetizing each animal in tricaine, the caudal end of the sympathetic chain was exposed, using the lateral approach described by Pick (1957). Ganglia 9 and 10 in 2 frogs and ganglia 8, 9, and 10 in 3 frogs were then removed unilaterally and separate sets of sutures were used to close incisions in the abdominal muscles and the skin. Following survival times of 14 to $60 \mathrm{~d}$, the animals were reanesthetized and target tissues on the control and operated sides were processed for immunocytochemistry as described above.

\section{Results}

\section{The distribution of immunoreactive cell bodies}

All paravertebral ganglia in the sympathetic system of the bullfrog were found to contain a subpopulation of neurons that exhibits NPY-like immunoreactivity. The staining was blocked entirely by omitting the anti-NPY serum or by preabsorbing the serum for $18 \mathrm{hr}$ at $4^{\circ} \mathrm{C}$ with $10^{-6} \mathrm{M}$ porcine NPY. Figure $1 \mathrm{a}$ illustrates the typical pattern of NPY-like immunoreactivity and was taken from a section of ganglion 3 . As a point of reference, 

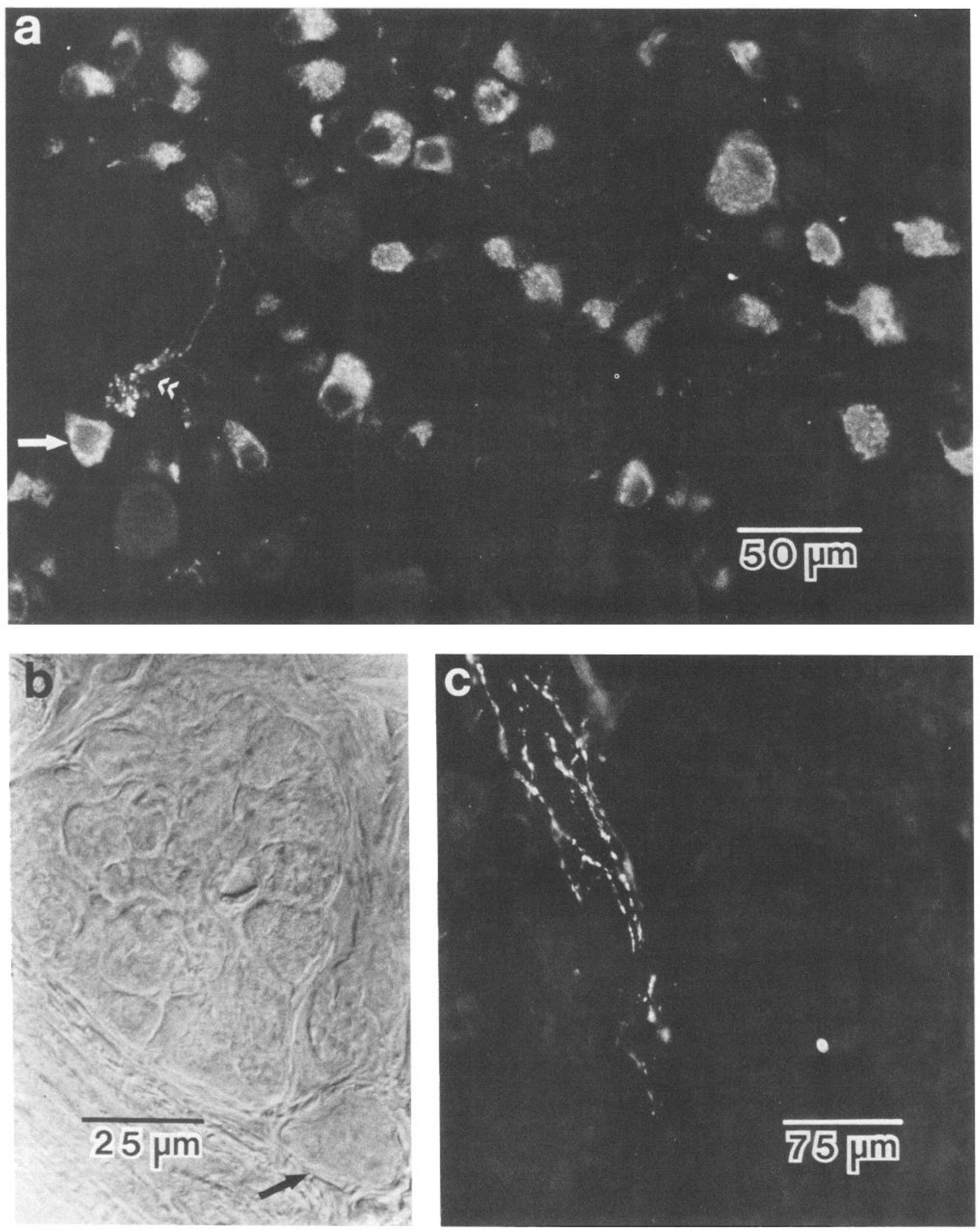

Figure 1. NPY-like immunoreactivity in sympathetic ganglion 3 and the adrenal gland. $a$, Immunofluorescent staining in paravertebral ganglion 3 is restricted to axons (double arrow) and to a subpopulation of principal neurons, many of which are relatively small. At the left is an island of nonimmunoreactive chromaffin cells. $b$, A photograph taken with Nomarski optics of the chromaffin cells in $a$. The single arrows in $a$ and $b$ point to the same neuron at the edge of the chromaffin cell cluster. Note the characteristically granular appearance of the chromaffin cells compared to that of the neuron (single arrow). $c$, Chromaffin cells in the adrenal gland do not stain, but there is a plexus of NPY-like immunoreactive fibers surrounding a blood vessel running through the section. 


\section{C cells}
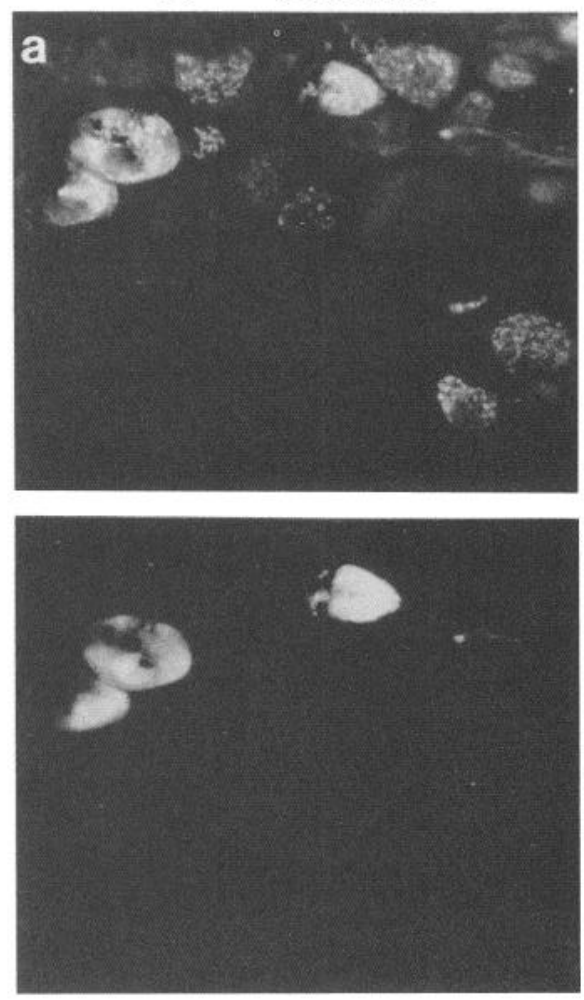

fast $B$ cells
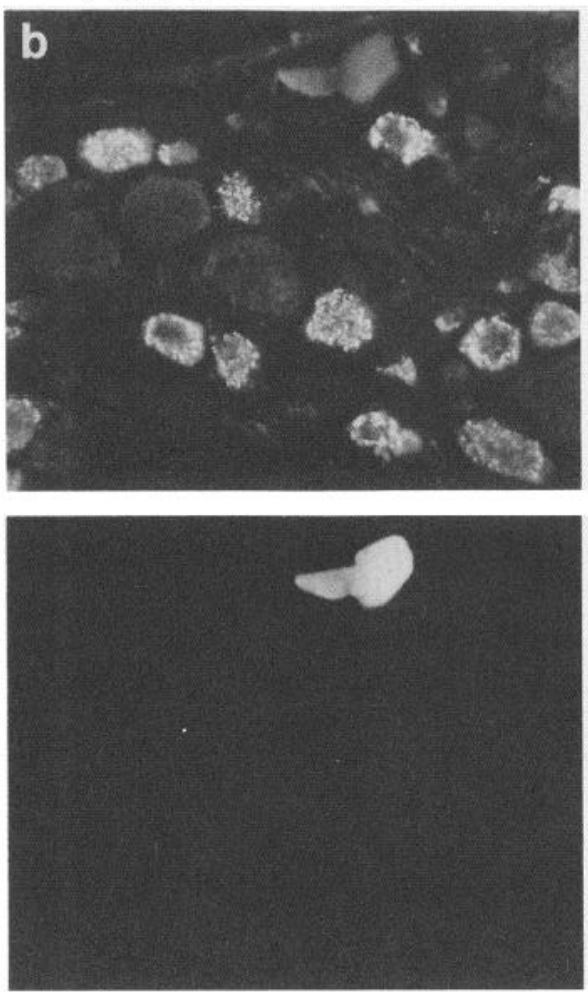

slow B cells
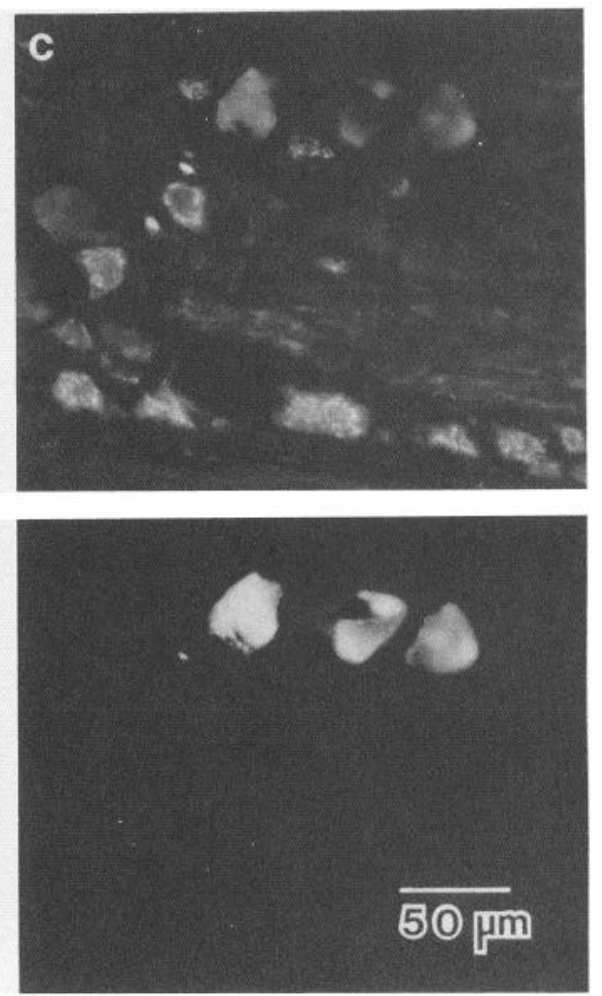

Figure 2. Double-labeling of sympathetic neurons in ganglia 9 and 10 with rabbit anti-NPY serum (upper panels) and with Lucifer yellow (lower panels). Lucifer yellow-injected C cells contain NPY-like immunoreactivity $(a)$, but dye-injected fast B cells $(b)$ and slow B cells $(c)$ do not contain NPY-like immunoreactivity.

ganglion 3 is attached by rami communicantes to spinal nerve 3 , which provides the main component of the brachial nerve. The immunoreactivity in all ganglia has a characteristic granular appearance and often is most dense in the perinuclear cytoplasm. In addition to cell bodies, some axons in the paravertebral ganglia are also immunoreactive.

Ganglionic chromaffin cells, which are also known as small intensely fluorescent, or SIF, cells, did not stain. The lack of immunoreactivity in a large cluster of SIF cells is illustrated in Figure 1a. Chromaffin cells were identified under Nomarski optics (Fig. $1 b$ ) by their small size and sparse granular cytoplasm (Weight and Weitsen, 1977; Dodd and Horn, 1983; Dunn and Marshall, 1985). As with ganglionic SIF cells, adrenal chromaffin cells were devoid of NPY-like immunoreactivity (Fig. 1c). Blood vessels running through the adrenal, however, were enmeshed by plexes of immunoreactive fibers that had numerous varicosities (Fig. 1c).

\section{Physiological identification of immunoreactive neurons}

Although there is overlap between the size distributions of B and $C$ cells in ganglia 9 and 10 , virtually all principal neurons with diameters of less than $30 \mu \mathrm{m}$ are C cells (Jan and Jan, 1982; Dodd and Horn, 1983). After looking at stained sections of ganglia, it was our impression that NPY-like immunoreactivity was most commonly seen in the smaller neurons. However, when examining cellular profiles in sections, it is difficult to infer the sizes of intact cells unless one undertakes laborious serial reconstructions and then applies statistical methods to a large sample of data. Therefore, size alone did not enable us to identify the entire population of immunoreactive neurons, but it did suggest that some were $\mathrm{C}$ cells. To further resolve this issue, a double-label paradigm was adopted in which individual neurons were identified physiologically, marked with Lucifer yellow dye, and then processed for NPY-like immunoreactivity. Physiological criteria for classifying neurons from ganglia 9 and 10 into 3 distinct groups have been described elsewhere (Dodd and Horn, 1983) but can be summarized briefly as follows (also see Table 1): $\mathrm{C}$ cells are innervated by slowly conducting preganglionic axons $(0.4 \mathrm{~m} / \mathrm{sec})$ that leave the cord via spinal nerves 7 and 8 and, in turn, the $C$ cells have slowly conducting axons $(0.3 \mathrm{~m} / \mathrm{sec})$. By contrast, B cells are innervated by more rapidly conducting preganglionic axons $(2.6 \mathrm{~m} / \mathrm{sec})$ that arise from spinal segments rostral to ganglion 7. B cells are further subdivided into fast B and slow B groups on the basis of their axonal conduction velocities, which, on average, are $2.5 \mathrm{~m} / \mathrm{sec}$ and 0.6 $\mathrm{m} / \mathrm{sec}$, respectively.

The optical qualities of bullfrog ganglia, in conjunction with the recording arrangement, enabled us to visualize individual neurons and to impale a given cell twice in succession-once for identification and a second time for dye injection. Each cell was first impaled with a $\mathrm{KCl}$-filled electrode and classified as a fast B-, slow B-, or C-type neuron. Both an antidromic action potential and an orthodromic synaptic response were recorded from every B cell that was filled, so that it could be classified as a fast $\mathrm{B}$ or slow $\mathrm{B}$ cell. Although antidromic action potentials were not recorded from all of the $\mathrm{C}$ cells included in our sample (Table 1), the segmental origin and conduction velocity of the orthodromic synaptic response allowed one to clearly distin- 
guish a $\mathrm{C}$ from a B cell. In every preparation $(n=17)$, an average of only 12 cells belonging to the same class was marked immediately after identification, using a separate Lucifer-filled electrode. The advantages of the 2-electrode technique were that it improved the quality of the physiological recordings because of the relatively low noise of $\mathrm{KCl}$-filled electrodes, and that it enabled us to mark cells of one type in each preparation, thereby simplifying the accounting for cells after sectioning. The resolution of the Nomarski optics (see plate 1, Dodd and Horn, 1983) made the double-impalement procedure reliable. The epifluorescent illuminator on the recording microscope was used to confirm the success of every dye fill at the time of injection. In this manner, it was possible to examine sections of the ganglia and to account for $96 \%(195 / 203)$ of the identified, dye-labeled cells prior to immunocytochemical processing.

The appearance of fast B, slow B, and C cells at the end of the double-labeling procedure is shown in Figure 2. In neurons that were heavily filled with Lucifer yellow there was some increase in background fluorescence when viewed with rhodamine filters. However, the diffuse background caused by Lucifer yellow injection was easily distinguished from the granular staining that characterizes NPY-like immunofluorescence (Fig. 2). Of 77 dye-filled neurons that contained NPY-like immunoreactivity, 76 were $\mathrm{C}$ cells, 1 was a fast $\mathrm{B}$ cell, and none were slow B cells (see Table 1). Whereas $98.7 \%$ of the immunoreactive neurons were C cells, only $88.3 \%$ of the identified C cells were immunoreactive. The average membrane potential of cells in the double-label experiments was $-44.6 \mathrm{mV}$ and did not vary systematically with cell type or with the presence of immunoreactivity.

\section{The number of immunoreactive neurons}

The preceding results indicate that NPY-like immunoreactivity is a reliable anatomical marker for C cells (see Discussion). We therefore undertook to estimate the percentage of neurons that are immunoreactive in order to determine the relative sizes of the $\mathrm{B}$ and $\mathrm{C}$ cell populations. For this purpose, ganglia 9 and 10 on one side in each of 3 animals were sectioned serially, reacted with anti-NPY serum and a second antibody coupled to HRP, and, finally, counterstained with thionin. This provided a permanent set of slides that were suitable for use in identifying nucleoli and in making camera lucida drawings of the labeled and unlabeled cellular profiles that contained nucleoli.

The appearance of NPY-like immunoreactivity in sections processed with an HRP-coupled second antibody is similar to that observed using indirect immunofluorescence. The brown reaction product is granular, often heavy, and most dense in the perinuclear cytoplasm (Fig. 3). Unlabeled neurons retain a typical Nissl-stained appearance: light blue cytoplasm and nucleus and deeply stained nucleoli. Both the peroxidase- and the rhodamine-coupled second antibodies reveal that neurons containing NPY-like immunoreactivity are distributed throughout ganglia 9 and 10 and that immunoreactive neurons are sometimes grouped into small clusters (Fig. 3).

The first ganglion that was analyzed quantitatively (case 1, ganglion 9) was cut into 70 serial sections. Camera lucida drawings of each section, in which each profile containing a nucleolus was drawn and scored for immunoreactivity, were prepared. Separate counts, based on every section and on every other section, were then tallied. After scaling the alternate counts by 2 , they fell within $4.5 \%$ of the serial counts. To simplify the subsequent analysis, cell counts in the other 5 ganglia were

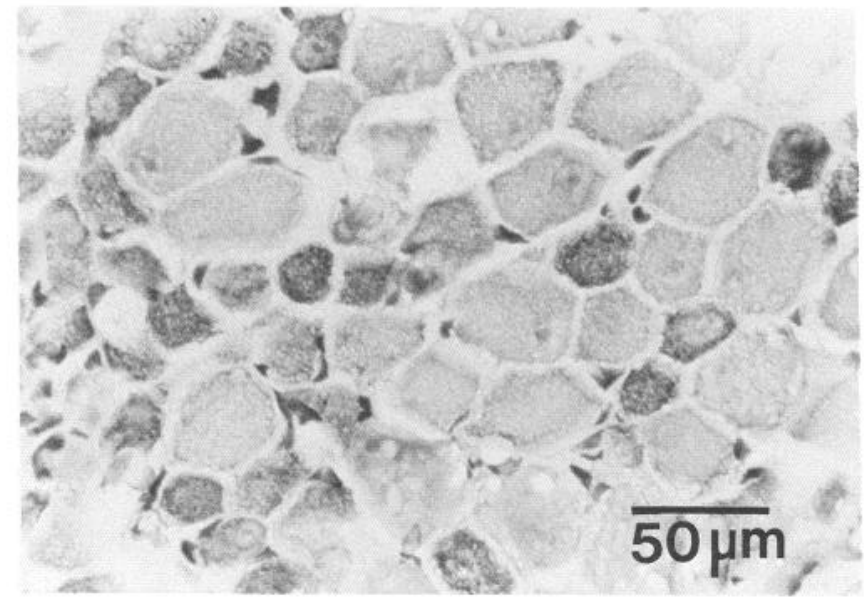

Figure 3. NPY-like immunoreactivity in a section of ganglion 10 that was processed using an HRP-coupled second antibody and counterstained with thionin. This photograph was taken with a CB12 blue filter to enhance the contrast between immunoreactive and nonimmunoreactive cells when rendered in black and white. Under these conditions the labeled cells are simply darker than the unlabeled cells. Although there is no distinct pattern in the distribution of labeled or unlabeled cells, occasional small clusters of like cells are a commonly observed feature in this material.

limited to alternate sections and multiplied by a factor of 2 . During the counting process, neuronal profiles that contained double nucleoli were also noted on the camera lucida drawings; these data are compiled in Table 2. Out of 29,465 cellular profiles in 6 ganglia, 1630 , or $5.5 \%$ of the total, contained double nucleoli and the remainder contained single nucleoli. From the data in Table 2, one can see that, overall, $51.4 \%$ of the profiles with double nucleoli was immunoreactive. To estimate the sizes of labeled and unlabeled cell populations from such data, one must consider the counting errors that result from the presence of cells with double nucleoli and from the splitting of nucleoli by the sectioning process. In principle, sectioning a cell that contains 2 nucleoli will occasionally result in 2 cellular profiles, each of which contains a single nucleolus. Consequently, counting the profiles that contain a nucleolus will lead to an overestimate of the total number of neurons in a ganglion. However, since the population of bullfrog sympathetic neurons with double nucleoli is relatively small, and since the presence of double nucleoli is uncorrelated with that of NPY-like immunoreactivity (Table 2), the existence of these cells seems unlikely either to introduce a large counting error or to bias our estimate of the percentage of neurons that are immunoreactive. Hence, no correction was made to deal explicitly with errors caused by sectioning through double nucleoli. Table 3 presents estimates of the total immunoreactive and nonimmunoreactive cell populations in ganglia 9 and 10 . These data were corrected for overcounting of split single nucleoli using factors that are described in Materials and Methods, based on the formula of Abercrombie (1946). The uncorrected raw counts are listed in parentheses (Table 3) and include all profiles with single and double nucleoli. Overall, $54.9 \%$ of 21,000 neurons in 6 ganglia contained NPYlike immunoreactivity. In the 3 animals that were studied, this value varied between 50.7 and $57.2 \%$.

\section{Axons of C-type neurons are associated with blood vessels}

As was mentioned earlier, NPY-like immunoreactivity in the adrenal gland was limited to axonal plexes near blood vessels 


\begin{tabular}{|c|c|c|c|c|}
\hline Ganglia & $\begin{array}{l}\text { No. of immuno- } \\
\text { reactive cells }\end{array}$ & $\begin{array}{l}\text { No. of nonimmu- } \\
\text { noreactive cells }\end{array}$ & $\begin{array}{l}\text { Total no. } \\
\text { of cells }\end{array}$ & $\begin{array}{l}\text { Cells that } \\
\text { were } \\
\text { immuno- } \\
\text { reactive } \\
(\%)\end{array}$ \\
\hline \multicolumn{5}{|l|}{ Ganglion 9} \\
\hline Case 1 & 88 & 110 & 198 & 44.4 \\
\hline Case 2 & 344 & 230 & 574 & 59.9 \\
\hline Case 3 & 78 & 90 & 168 & 46.4 \\
\hline Subtotal & 510 & 430 & 940 & 54.2 \\
\hline \multicolumn{5}{|l|}{ Ganglion 10} \\
\hline Casc 1 & 54 & 76 & 130 & 41.5 \\
\hline Case 2 & 182 & 188 & 370 & 49.1 \\
\hline Case 3 & 92 & 98 & 190 & 48.4 \\
\hline Subtotal & 328 & 362 & 690 & 47.5 \\
\hline Grand total & 838 & 792 & 1630 & 51.4 \\
\hline
\end{tabular}

Neuronal profiles that contained double nucleoli were counted in every section of ganglion 9 , case 1 . In the remaining cases, every other section was analyzed and the counts were multiplied by a factor of 2 . The data are uncorrected for split nucleoli. With the exception of the right-hand column, all subtotals and grand totals are the sums of the counts in a given column. In the right-hand column, each percentage has been calculated from values in the corresponding row of the table.

(Fig. 1c). To characterize further the peripheral projections of $\mathrm{C}$ cells, we examined hindlimb skin and the sartorius muscle for NPY-like immunoreactivity because electrophysiological evidence indicates that these tissues contain axons of $\mathrm{C}$ cells whose somata are located in ganglia 9 and 10 (Horn et al., 1985, 1986).

In green dorsal skin and white ventral skin from the hindlimb, a sparse network of fibers containing NPY-like immunoreactivity was present in the subdermal vascular and nerve plexes and in all layers of the dermis, but not in the epidermis. Although they were similar in their cutaneous distribution, the density of labeled axons appeared to be higher in dorsal than in ventral skin. The labeled axons always had numerous varicosities. Figure 4 illustrates a transverse section through green dorsal skin from the thigh. At the base of the skin, there are 2 large blood vessels and a nerve bundle that are cut transverse to their longitudinal axes. Within the nerve are several small dots of immunoreactivity that correspond to end-on views of cut axons. Surrounding the large blood vessels one can see longer segments of immunoreactive axons. In this same section, 3 small blood

Table 3. Counts of sympathetic neurons in ganglia stained for NPY-like immunoreactivity

\begin{tabular}{|c|c|c|c|c|}
\hline Ganglia & $\begin{array}{l}\text { No. of immuno- } \\
\text { reactive cells }\end{array}$ & $\begin{array}{l}\text { No. of nonimmuno- } \\
\text { reactive cells }\end{array}$ & $\begin{array}{l}\text { Total no. } \\
\text { of cells }\end{array}$ & $\begin{array}{l}\text { Cells that } \\
\text { were } \\
\text { immuno- } \\
\text { reactive } \\
(\%)\end{array}$ \\
\hline \multicolumn{5}{|l|}{ Ganglion 9} \\
\hline Case 1 & $1911(2618)$ & $1605(2293)$ & 3516 & 54.3 \\
\hline Casc 2 & $3143(4306)$ & $2338(3340)$ & 5481 & 57.3 \\
\hline Case 3 & $1602(2194)$ & $997(1424)$ & 2599 & 61.6 \\
\hline Subtotal & $6656(9118)$ & $4940(7057)$ & 11,596 & 57.3 \\
\hline Mean & 2219 & 1647 & 3866 & - \\
\hline \multicolumn{5}{|l|}{ Ganglion 10} \\
\hline Case 1 & $1079(1478)$ & $1352(1932)$ & 2431 & 44.3 \\
\hline Case 2 & $2290(3138)$ & $1828(2612)$ & 4118 & 55.6 \\
\hline Case 3 & $1575(2158)$ & $1380(1972)$ & 2955 & 53.2 \\
\hline Subtotal & $4944(6774)$ & $4560(6516)$ & 9504 & 52.0 \\
\hline Mean & 1648 & 1520 & 3168 & - \\
\hline Grand total & $11,600(15,892)$ & $9500(13,573)$ & 21,100 & 54.9 \\
\hline
\end{tabular}

In every section of ganglion 9 , case 1 , all profiles containing a piece of a nucleolus were counted. In the remaining cases every other section was analyzed and the results were multiplied by a factor of 2 to yield raw counts. These raw counts are listed in parentheses to the right of values that are corrected for double-counting of cells with split nucleoli. The correction factors used were 0.73 for immunoreactive cells and 0.70 for nonimmunoreactive cells. The origin of these corrections is explained in Materials and Methods. 


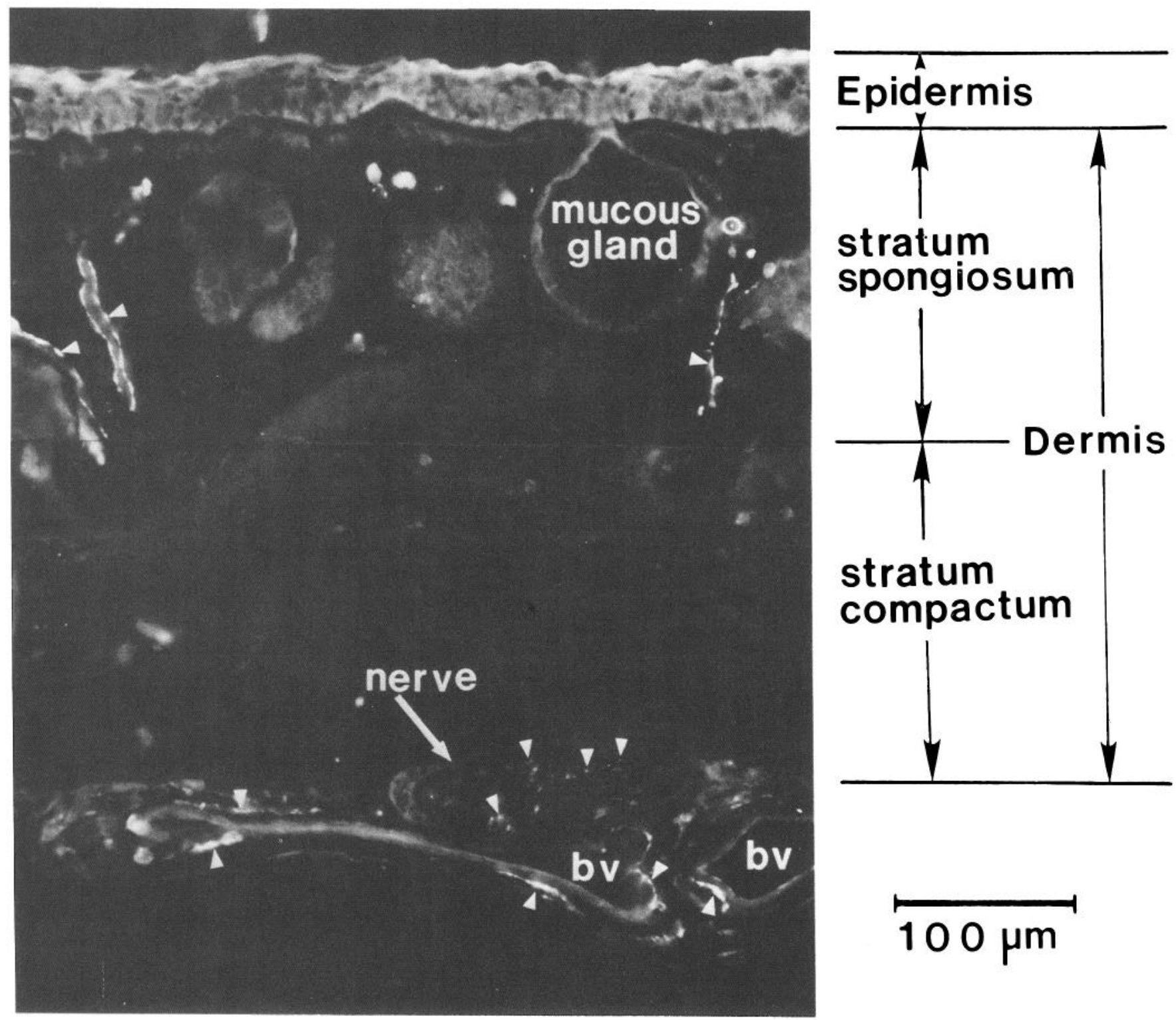

Figure 4. NPY-like immunoreactivity in a transverse section of green dorsal skin taken from the thigh. Nonspecific background fluorescence was higher in the epidermis than in the dermis. Arrowheads point to examples of immunoreactive axons. Labeled axons are most prominent within cutaneous nerve bundles and in close association with subdermal blood vessels $(b v)$ and small blood vessels that traverse the stratum spongiosum.

vessels that are traversing the stratum spongiosium are surrounded by immunoreactive axons. Although not prominent in Figure 4 , immunoreactive axons were observed occasionally in the stratum compactum.

To examine further the distribution of cutaneous axons containing NPY immunoreactivity, some skin was sectioned parallel to its surface. Figure 5 illustrates the appearance of such horizontal sections at the level of cutaneous glands (Fig. 5, ac), subdermal blood vessels (Fig. 5, $d, e$ ), and subdermal nerves (Fig. $5, e, f$ ). Immunoreactive axons were seen often in close association with cutaneous mucous glands but not with granular glands. Although labeled axons sometimes appeared to make contact with mucous glands, the axons were never observed penetrating the walls of glands. The highest density of labeled axons seen in skin was in association with large subdermal blood vessels. This was especially apparent when vessels were viewed along their longitudinal axis (Fig. 5, $d, e$ ). Similarly, the faint dots of immunofluorescence that are seen when subcutaneous nerves are cut in transverse section (Fig. 4) could be easily identified as small axons when viewed in an orthogonal plane (Fig. 5, $e, f$ ).

In the sartorius muscle, axons containing NPY-like immunoreactivity were always found in close proximity to arteries and small blood vessels that were probably capillaries. Since an average of only 15 sympathetic axons project to the sartorius muscle (J. P. Horn and W. D. Stofer, unpublished observations), pieces of muscle were processed as whole mounts in order to determine the distribution of immunoreactive axons. At their points of insertion into the muscle, the sartorius motor nerve and artery, but not the vein, contained labeled axons. A whole mount of the sartorius artery at its point of insertion is shown in Figure 6. As in the adrenal gland and skin, labeled axons in striated muscle had many varicosities. Within the sartorius muscle, labeled axons continued to follow arteries and to bifurcate at vascular branch points (Fig. 7). As the branching arteries became smaller in diameter, the accompanying axons some- 

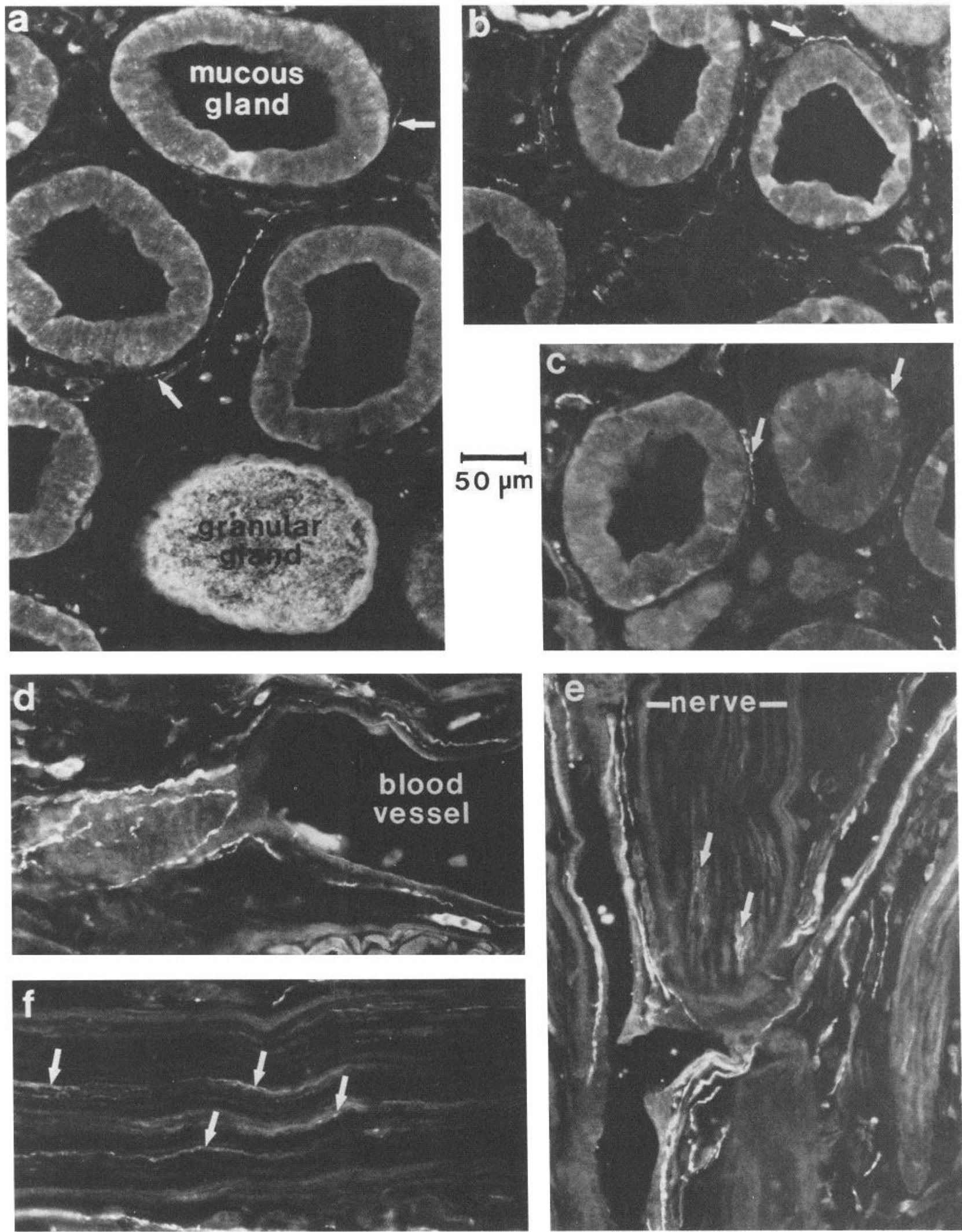

Figure 5. NPY-like immunoreactivity in a horizontal section of green dorsal skin. This tissue came from the same region and animal as that in Figure 4. Arrowheads point to immunoreactive axons. In the stratum spongiosum $(a, b, c)$, numerous labeled axons are present. They occasionally appear to touch the basal surface of mucous glands but were never observed penetrating the glandular epithelium. $a$, Several mucous glands and an example of a granular gland that contained characteristic autofluorescent granules. Immunoreactive axons were not observed in the immediate vicinity of granular glands. $b, c$, Additional examples of labeled axons near mucous glands. The sections in $d, e$, and $f$ were cut at the level of the subdermal plexes. In $d$, the section cuts through a relatively small branch of a vessel on the left and down the lumen of a large vessel on the right. 

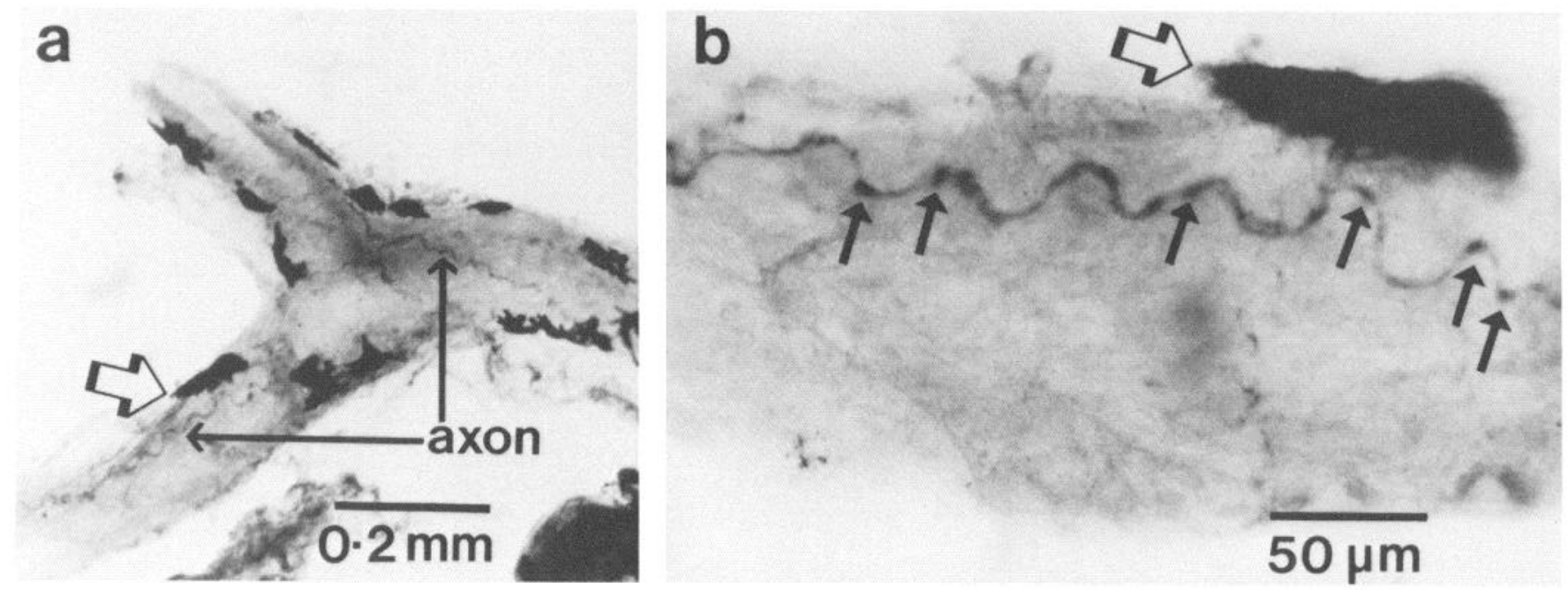

Figure 6. NPY-like immunoreactivity in a whole mount preparation of the sartorius artery at its point of insertion into the muscle. In the lowpower view $(a)$, one can make out several labeled axons. The higher-power view $(b)$ is of the same preparation. Hollow arrows point to the same pigment cell in both $a$ and $b$. Solid arrows in $b$ point to varicosities in the labeled axon.

times appeared outside the wall of the blood vessel. In several cases where we have been able to identify capillaries by their small caliber and the presence of blood cells in single file, nearby labeled axons were observed (Fig. $7 b$ ).

To determine whether the immunoreactive axons in the skin and sartorius muscle originated from lumbar sympathetic ganglia, paravertebral ganglia 9 and 10 were removed unilaterally from 2 frogs and ganglia 8,9 , and 10 were removed unilaterally from 3 additional frogs. After survival times of $14 \mathrm{~d}$ to 2 months, the skin and sartorius muscles on both control and experimental sides were processed for NPY-like immunoreactivity. Removal of ganglia 9 and 10 resulted in the disappearance of virtually all NPY-like immunoreactivity within $14 \mathrm{~d}$. Removing ganglion 8 in addition to 9 and 10 and allowing the animals to survive for up to $60 \mathrm{~d}$ had the same effect as removing only ganglia 9 and 10 .

\section{Discussion}

These present experiments demonstrate that a large subpopulation of bullfrog sympathetic neurons express NPY-like immunoreactivity. In the ninth and tenth paravertebral ganglia, this immunoreactivity is expressed selectively by a single electrophysiologically identifiable class of neurons-the $\mathrm{C}$ cells. Together with our other findings, the significance of these results is threefold. First, they provide a histological marker that can be used to identify $\mathrm{C}$ cells in anatomical experiments. Second, they suggest that, in C cells, an NPY-like molecule may act as a cotransmitter with epinephrine. Finally, they suggest that $\mathrm{C}$ cells function as vasomotor neurons. We will consider these possibilities in turn.

\section{Is NPY-like immunoreactivity a marker for $C$ cells?}

Although the data from the double-label experiments (Table 1) show that the vast majority of immunoreactive neurons were $\mathrm{C}$ cells, it is also true that 10 of $86 \mathrm{C}$ cells were not immuno- reactive and that 1 of 99 fast and slow B cells was immunoreactive. Although this could mean that a small subset of $C$ cells does not contain NPY-like immunoreactivity and that an even smaller subset of fast B cells are immunoreactive, alternative explanations seem equally feasible. Since the level of immunoreactivity in dye-filled cells (Fig. 2) was often lower than that in neighboring cells, it seems plausible that damage due to double impalement could have degraded antigenic molecules. Such a loss of antigen, in conjunction with the small increase in nonspecific background that is caused by Lucifer yellow, may have obscured immunoreactivity in the $12 \%$ of $\mathrm{C}$ cells that were negative. An artifact of this magnitude fails, however, to account for the observation that $99 \%$ of the B cells were not immunoreactive. As for the 1 immunoreactive fast $B$ cell that was observed, it could represent an exceedingly rare cell type or it may simply have resulted from an error in our method. Another interpretation of these findings is possible if one assumes that some cells express very low levels of NPY-like immunoreactivity. According to this view, one might argue that both B and C cells express NPY-like immunoreactivity, but that the expression in B cell somata is below our threshold for detection. Although this possibility is difficult to refute, the fact remains that NPY-like immunoreactivity is detected easily in C cell somata and in the fine processes of $\mathrm{C}$ axons, but not in $\mathrm{B}$ cell bodies. Definitive resolution of this issue will require more sensitive methods and would be facilitated by a direct examination of gene expression underlying the observed immunoreactivity. Further interpretation of the present results concerning nonimmunoreactive $\mathrm{C}$ cells will not be possible until independent markers for fast $\mathrm{B}$, slow $\mathrm{B}$, and $\mathrm{C}$ cells are discovered. With such tools it should become possible to delineate more fully the cellular distribution of NPY-like immunoreactivity and to qualify more precisely its definition as a marker for $\mathrm{C}$ cells.

The absence of NPY-like immunoreactivity in bullfrog chromaffin cells in ganglia and in adrenal gland is consistent with

$e$, An example of a Y-shaped blood vessel surrounded by the dense plexus of labeled axons. At the branching of the $\mathrm{Y}$, the section cuts through a nerve trunk that contains several labeled axons denoted by arrows. $f$, Another example of a subdermal nerve trunk that contains immunoreactive axons. 

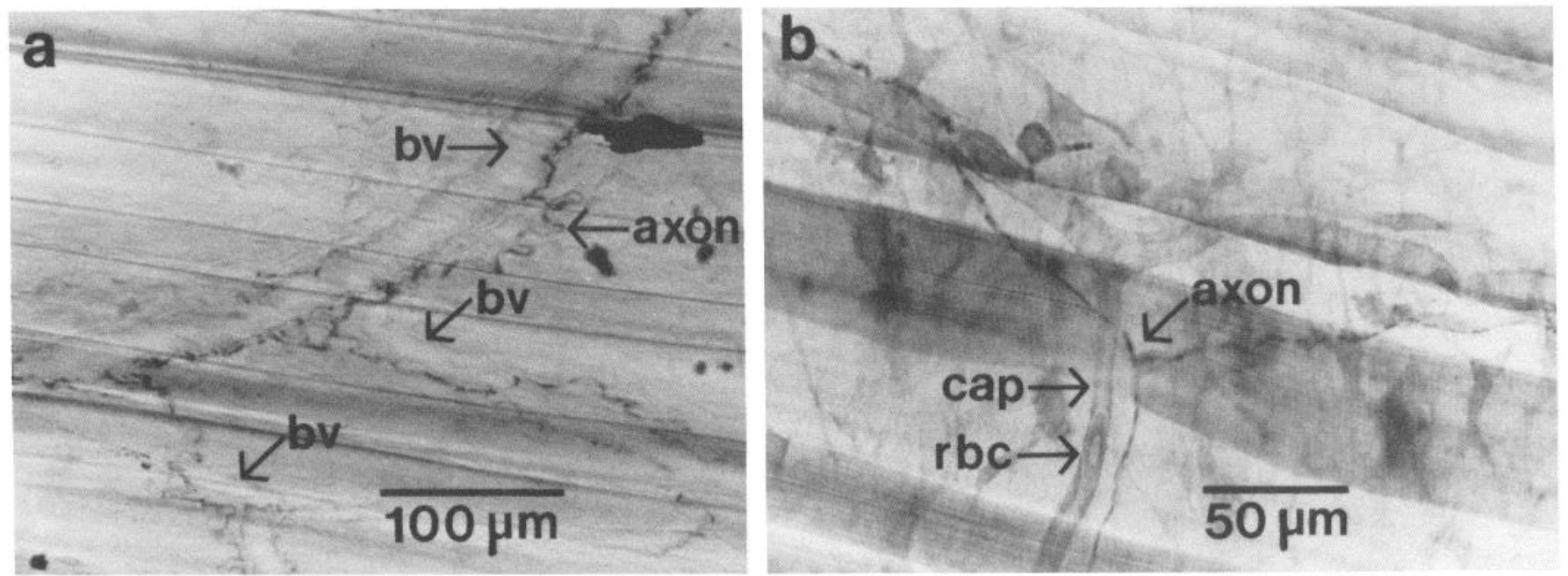

Figure 7. NPY-like immunoreactivity in axons within the sartorius muscle. Striated muscle fibers run horizontally in both $a$ and $b$. In $a$, a small blood vessel $(b v)$ surrounded by labeled axons extends from the lower left to upper right corners of the picture. At each vascular branch point in this field there is an axonal bifurcation. The 2 smaller blood vessels are difficult to distinguish in this plane of focus but are marked by arrows labeled $b v$. Note that the immunoreactive axons in $a$ do not appear as an integral part of the vascular wall. At the arrow marked axon, the fiber is clearly separated from the accompanying blood vessel for about $50 \mu \mathrm{m}$. Thus it appears that the association between immunoreactive axons and blood vessels becomes less intimate as the blood vessels become smaller in caliber. Unlike all other data in this paper, $b$ is taken from the sartorius muscle of a 2 in. grass frog, Rana pipiens. We found no difference in the distribution of immunoreactivity between species and present this picture because of the optical quality of this relatively thin specimen. Note the branching capillary (cap) that is accompanied by a branching labeled axon and the red blood cell $(r b c)$ within the lumen of the capillary.

the notion that NPY expression by chromaffin tissue varies greatly between species. For example, Lundberg et al. (1983) reported that immunoreactive SIF cells are present in ganglia of the mouse and guinea pig, but not in rat, cat, dog, pig, or man. Similarly, NPY has been found in subpopulations of adrenal chromaffin cells in several mammalian species (Varndell et al., 1984; Majane et al., 1985), but the levels expressed by different species are quite different (Allen et al., 1983a).

\section{NPY as a putative neurotransmitter}

In the mammalian sympathetic system, a combination of biochemical, anatomical, and physiological evidence supports the hypothesis that NPY functions as a cotransmitter with norepinephrine (see the introduction). By analogy, it is tempting to propose that NPY-like immunoreactivity in the bullfrog sympathetic system is due to a related antigenic molecule that acts as a cotransmitter with epinephrine. However, until the bullfrog antigen is characterized in terms of its structure and physiological actions, little can be said about its hypothetical function. With these questions in mind, it is interesting to note that in preliminary experiments we have found that stimulation of the bullfrog sympathetic system in the presence of an alpha-adrenergic antagonist produces a vasoconstriction that can be mimicked by close arterial injection of authentic porcine NPY (Fatherazi et al., 1986).

\section{Do $C$ cells function as vasomotor neurons?}

Although it is well established in the frog that sympathetic ganglia innervate blood vessels (Langley, 1911), glands (Skoglund and Sjoberg, 1977), and cutaneous sensory receptors (Loewenstein, 1956; Spray, 1974), the peripheral targets of C cells were not identified in these earlier reports. Using extracellular recordings, Horn et al. (1985) have shown that C cell axons, unlike those of B cells, project from ganglia 9 and 10 into visceral and voluntary motor nerves, as well as into cutaneous nerves. In the present study, NPY-like immunoreactivity in the sartorius muscle and in skin was found to be most commonly associated with large arteries and smaller blood vessels. Since most NPYlike immunoreactivity in the hindlimb was eliminated after surgical removal of ipsilateral ganglia 9 and 10 , it seems very likely that most of the labeled axons originated from $\mathrm{C}$ cells in these ganglia. It is also possible that the experimental surgery disrupted a few immunoreactive fibers that originated from cells in more rostral ganglia and passed through ganglia 9 and 10 on their way to the periphery. We cannot account for the occasional immunoreactive axon that was observed in target tissues after removal of the ipsilateral ganglia. Although the vasculature may be a major target of C cells, this possibility has not been explicitly tested in these experiments. However, the notion of a vasomotor role is supported by a brief report that stimulation of $\mathrm{C}$ cells in the toad can reduce blood flow (Honma, 1970) and by preliminary experiments in which we have found that stimulation of $\mathrm{C}$, but not $\mathrm{B}$, cells produces vasoconstriction in the bullfrog (Horn et al., 1986). Finally, we cannot rule out the possibility that tissues other than blood vessels (e.g., mucous glands) are also targets of the $\mathrm{C}$ axons.

\section{How should a $C$ cell be defined?}

In an earlier study, Dodd and Horn (1983) mapped the distribution of $B$ and $C$ cells in ganglia 9 and 10 by systematically impaling and electrophysiologically identifying the majority of neurons that occupied several adjacent microscope fields. They found that $B$ and $C$ cells were distributed throughout both ganglia and that there was a slight tendency for clustering of cells belonging to each group. The present experiments have confirmed and extended these findings, using NPY-like immunoreactivity as a marker for $\mathrm{C}$ cells. For the first time it has been possible to estimate the proportion of neurons that are $\mathrm{C}$ cells. Assuming the adequacy of the marker, we find that $55 \%$ of the neurons in ganglia 9 and 10 are $C$ cells. In our corrected counts, we did not correct for double nucleoli, nor have we verified the accuracy of Abercrombie's (1946) method in this system. How- 
ever, the presence of immunoreactivity is not correlated with that of double nucleoli (Table 2), and our correction factors for B cells $(0.70)$ and $C$ cells $(0.73)$ are very similar. Therefore, the largest uncertainties in our estimates are in the absolute numbers of sympathetic neurons in ganglia 9 and 10 , and not in the relative proportions of $\mathrm{B}$ and $\mathrm{C}$ cells.

The most important conclusion of the cell-counting experiments is that $C$ cells constitute a slight majority of the neurons in ganglia 9 and 10 . Although a systematic count of neurons has not been undertaken in ganglia rostral to segment 9 , it is clear that neurons containing NPY-like immunoreactivity comprise a large fraction of the sympathetic system throughout the remainder of the paravertebral chain (e.g., Fig. 1a). Are all these neurons $\mathrm{C}$ cells? The present electrophysiological criteria for defining a $\mathrm{C}$ ccll include pre- and postganglionic conduction velocities and the segmental origin of preganglionic axons (Dodd and Horn, 1983). It seems unlikely that these criteria will be directly applicable to other segmental ganglia. However, a modification of the present criteria that relaxes references to specific segments and includes immunoreactivity and target specificity may make it possible to develop a classification scheme that applies to all segmental levels in the bullfrog sympathetic chain and even to other species.

\section{References}

Abercrombie, M. (1946) Estimation of nuclear population from microtome sections. Anat. Rec. 94: 239-247.

Allen, J. M., T. E. Adrian, J. M. Polak, and S. R. Bloom (1983a) Neuropeptide Y (NPY) in the adrenal gland. J. Auton. Nerv. Syst. 9: 559-563.

Allen, J. M., P. M. M. Bircham, A. V. Edwards, K. Tatemoto, and S. R. Bloom (1983b) Neuropeptide Y (NPY) reduces myocardial perfusion and inhibits the force of contraction of the isolated perfused rabbit heart. Regulat. Pept. 6: 247-253.

Costa, M., R. Buffa, J. B. Furness, and E. Solcia (1980) Immunohistochemical localization of polypeptides in peripheral autonomic nerves using whole mount preparations. Histochemistry 65: 157-165.

Dodd, J., and J. P. Horn (1983) A reclassification of B and C neurones in the ninth and tenth paravertebral sympathetic ganglia of the bullfrog. J. Physiol. (Lond.) 334: 255-269.

Dunant, Y. (1967) Organisation topographique et fonctionnelle du ganglion cervical supérieur chez le rat. J. Physiol. (Paris) 59: 17-38.

Dunn, P. M., and L. M. Marshall (1985) Innervation of small intensely fluorescent cells in frog sympathetic ganglia. Brain Res. 339: 371374.

Edvinsson, L., P. Emson, J. McCulloch, K. 'Tatemoto, and R. Uddman (1983) Neuropeptide Y: Cerebrovascular innervation and vasomotor effects in the cat. Neurosci. Lett. 43: 79-84.

Edwall, B., B. Gazelius, A. Fazekas, E. Theodorsson-Norheim, and J. Lundberg (1985) Neuropeptide Y (NPY) and sympathetic control of blood flow in oral mucosa and dental pulp in the cat. Acta Physiol. Scand. 125: 253-264.

Erulkar, S. D., and J. K. Woodward (1968) Intracellular recording from mammalian superior cervical ganglion in situ. J. Physiol. (Lond.) 199: 189-203.

Fatherazi, S., W. D. Stofer, and J. P. Horn (1986) Application of neuropeptide $Y$ can mimic non-adrenergic sympathetic vasoconstriction in the bullfrog. Soc. Neurosci. Abstr. 12: 542.

Franco-Cereceda, A., J. M. Lundberg, and C. Dahlof (1985) Neuropeptide $\mathrm{Y}$ and sympathetic control of heart contractility and coronary vascular tone. Acta Physiol. Scand. 124: 361-369.

Gu, J., J. M. Polak, T. E. Adrian, J. M. Allen, K. Tatemoto, and S. R. Bloom (1983) Neuropeptide tyrosine (NPY) - a major cardiac neuropeptide. Lancet $1: 1008-1010$.

Hartman, D. A., and J. Krier (1984) Synaptic and antidromic potentials of visceral neurones in ganglia of the lumbar sympathetic chain of the cat. J. Physiol. (Lond.) 350: 413-428.

Hellstrom, P. M., O. Olerup, and K. Tatemoto (1985) Neuropeptide Y may mediate effects of sympathetic nerve stimulations on colonic motility and blood flow in the cat. Acta Physiol. Scand. 124: 613624.
Honma, S. (1970) Functional differentiation in $\mathrm{sB}$ and $\mathrm{sC}$ neurons of toad sympathetic ganglia. Jpn. J. Physiol. 20: 281-295.

Horn, J. P., W. D. Stofer, and S. Fatherazi (1985) Identified subclasses of bullfrog sympathetic neurons project to different types of peripheral targets. Soc. Neurosci. Abstr. 11: 64.

Horn, J. P., S. Fatherazi, and W. D. Stofer (1986) Selective innervation of blood vessels in the bullfrog by sympathetic $C$ neurons that contain neuropeptide-Y like immunoreactivity. Soc. Neurosci. Abstr. 12:542.

Jan, L. Y., and Y. N. Jan (1982) Peptidergic transmission in sympathetic ganglia of the frog. J. Physiol. (Lond.) 327: 219-246.

Janig, W., and P. Szulczyk (1981) The organization of lumbar preganglionic neurons. J. Auton. Nerv. Syst. 3: 177-191.

Konigsmark, B. W. (1970) Methods for the counting of neurons. In Contemporary Research Methods in Neuroanatomy, W. J. H. Nauta and S. O. F. Fbbesson, eds., pp. 315-340, Springer-Verlag, New York.

Kuffler, S. W. (1980) Slow synaptic responses in autonomic ganglia and the pursuit of a peptidergic transmitter. J. Exp. Biol. 89: 257286

Langley, J. N. (1911) The origin and course of the vaso-motor fibres of the frog's foot. J. Physiol. (Lond.) 41: 483-498.

Loewenstein, W. R. (1956) Modulation of cutaneous mechanoreceptors by sympathetic stimulation. J. Physiol. (Lond.) 132: 40-60.

Lundberg, J. M., and L. Stjarne (1984) Neuropeptide Y (NPY) depresses the secretion of ${ }^{3} \mathrm{H}$-noradrenaline and the contractile response evoked by field stimulation in rat vas deferens. Acta Physiol. Scand. 120: $477-479$

Lundberg, J. M., T. Hökfelt, A. Anggard, L. Terenius, R. Elde, K. Markey, M. Goldstein, and J. Kimmel (1982a) Organizational principles in the peripheral sympathetic nervous system: Subdivision by coexisting peptides (somatostatin-, avian pancreatic polypeptide-, and vasoactive intestinal polypeptide-like immunoreactive materials). Proc. Natl. $\Lambda$ cad. Sci. US $\Lambda$ 79: 1303-1307.

Lundberg, J. M., L. Terenius, T. Hökfelt, C. R. Marîling, K. Tatemoto, V. Mutt, J. Polak, S. Bloom, and M. Goldstein (1982b) Neuropeptide Y (NPY)-like immunoreactivity in peripheral noradrenergic neurons and effects of NPY on sympathetic function. Acta Physiol. Scand. 116: $477-480$

Lundberg, J. M., L. Terenius, T. Hökfelt, and M. Goldstein (1983) High levels of neuropeptide $\mathrm{Y}$ in peripheral noradrenergic neurons in various mammals including man. Neurosci. Lett. 42: 167-172.

Lundberg, J. M., L. Terenius, T. Hökfelt, and K. Tatemoto (1984) Comparative immunohistochemical and biochemical analysis of pancreatic polypeptide-like peptides with special reference to presence of neuropeptide $\mathrm{Y}$ in central and peripheral neurons. J. Neurosci. 4 . 2376-2386.

Majane, E. A., H. Alho, Y. Kataoka, C. H. Lee, and H.-Y. T. Yang (1985) Neuropeptide $Y$ in bovine adrenal glands: Distribution and characterization. Endocrinology 117: 1162-1168.

Perri, V., O. Sacchi, and C. Casella (1970) Electrical properties and synaptic connections of the sympathetic neurons in the rat and guineapig superior cervical ganglion. Pfluegers Arch. 314: 40-54.

Pick, J. (1957) Sympathectomy in amphibians. J. Comp. Neurol. 107: 169-207.

Skoglund, C. R., and Sjoberg, E. (1977) In vivo studies of individual mucous glands in the frog. Acta Physiol. Scand. 100: 471-484.

Spray, D. C. (1974) Characteristics, specificity, and efferent control of frog cutaneous cold receptors. J. Physiol. (I ond.) 237: 15-38.

Stjernquist, M., P. Emson, C. Owman, N.-O. Sjoberg, F. Sundler, and K. Tatemoto (1983) Neuropeptide $Y$ in the female reproductive tract of the rat. Distribution of nerve fibres and motor effects. Neurosci. Lett. 39: 279-284.

Tatemoto, K. (1982) Neuropeptide Y: Complete amino acid sequence of the brain peptide. Proc. Natl. Acad. Sci. USA 79: 5485-5489.

Tatemoto, K., M. Carlquist, and V. Mutt (1982) Neuropeptide Y-a novel brain peptide with structural similarities to peptide $Y Y$ and pancreatic polypeptide. Nature 296: 659-660.

Varndell, I. M., J. M. Polak, J. M. Allen, G. Terenghi, and S. R. Bloom (1984) Neuropeptide tyrosine (NPY) immunoreactivity in norepinephrine-containing cells and nerves of the mammalian adrenal gland. Endocrinology 114: 1460-1462.

Wallis, D. I., and R. A. North (1978) Synaptic inputs to cells of the rabbit superior cervical ganglion. Pfluegers Arch. 374: 145-152.

Weight, F. F., and H. A. Weitsen (1977) Identification of small intensely fluorescent (SIF) cells as chromaffin cells in bullfrog sympathetic ganglia. Brain Res. 128: 213-226. 